\title{
QUEEN'S
UNIVERSITY
BELFAST
}

\section{Situated regional university incubation: A multi-level stakeholder perspective}

McAdam, M., Miller, K., \& McAdam, R. (2016). Situated regional university incubation: A multi-level stakeholder perspective. Technovation, 50-51, 69-78. https://doi.org/10.1016/j.technovation.2015.09.002

\section{Published in:}

Technovation

\section{Document Version:}

Peer reviewed version

Queen's University Belfast - Research Portal:

Link to publication record in Queen's University Belfast Research Portal

\section{Publisher rights}

(C) 2016. This manuscript version is made available under the CC-BY-NC-ND 4.0 license http://creativecommons.org/licenses/by-ncnd/4.0/which permits distribution and reproduction for non-commercial purposes, provided the author and source are cited.

\section{General rights}

Copyright for the publications made accessible via the Queen's University Belfast Research Portal is retained by the author(s) and / or other copyright owners and it is a condition of accessing these publications that users recognise and abide by the legal requirements associated with these rights.

Take down policy

The Research Portal is Queen's institutional repository that provides access to Queen's research output. Every effort has been made to ensure that content in the Research Portal does not infringe any person's rights, or applicable UK laws. If you discover content in the Research Portal that you believe breaches copyright or violates any law, please contact openaccess@qub.ac.uk. 


\title{
An Exploratory study of Situated Regional University Incubation: A Multi-level Stakeholder Perspective
}

\begin{abstract}
From a macro perspective, it is widely acknowledged that University incubation models within a region are important stimulants of economic development through innovation and job creation. With the emergence of quadruple helix innovation ecosystems, universities have had re-evaluate their University incubation activity and models to engage more fully with industry and end users. However, within a given region, the type of University may influence their ability to engage with quadruple helix stakeholders and consequently impact their incubation activity. To date there is a scarcity of research which explores this 'meso' environment and its subsequent impact on University incubation models. Therefore, the aim of this paper is to use a stakeholder lens to explore University Incubation models within unique regional and organisational characteristics and constraints. The research methodology employed was based on a comparative case analysis of incubation of two different Universities within a UK peripheral region. It was found that variances existed in relation to the two universities incubation models which were found to result from both regional (macro environment) and organisational (meso environment) influences (i.e. university type).This research contributes to both regional and national agendas by empirically illustrating the need for appropriate design and tailoring of university incubation models (via acknowledgment of quadruple helix stakeholder influence) to incorporate contextual influences rather than adopting a best practice approach.
\end{abstract}

Key words: University Incubation Models; Regional Context; Stakeholder Theory; Comparative Case Study Analysis.

\section{Introduction}

It is widely recognised that sustainable economic development is dependent on the stimulation of innovation and new firm formation within regions (Mian, 2011; Liargovas, 2013). From the early 1980s, University Incubation models have emerged within the wider University Technology Transfer (UTT) process as effective mechanisms for nurturing and supporting spin-out firms (Allen and Rahman, 1985; Lewis, 2001; Voisey et al., 2006). Since then, such models have emerged globally with the aim of stimulating economic development and growth (Mian, 2011). Within the literature, although the process of incubation varies, it is generally considered to incorporate mentoring and knowledge exchange between various stakeholders to enhance sustainability and growth (Hackett and Dilts, 2008; Wonglimpiyarat, 2010; Ahmad, and Ingle, 2011). Consequently, it is an interactive process often involving interorganisational collaboration between government, universities, industry and end user stakeholders (Garrett-Jones et al., 2005; Fogelberg and Sandén, 2008; Howells, 2012).

Recent research identifies the need to consider contextual factors when exploring incubation processes in a regional setting (Liargovas, 2013; Carayannis and Rakhmatullin, 2014; Zahra et al., 2014). Although both Phan et al., (2005) and Tamasy (2007) refer to the impact of regional contextual factors on incubation, to date this is an underexplored area lacking a consistent 
theoretical foundation (Oakey, 2012). In addition, Daskalopoulou et al., (2010) suggest there is likely to be variances in university incubation models and performance across regions. This approach contrasts with a universal best practice ethos applicable across all regions and suggests the need to identify and leverage unique and idiosyncratic regional influences on university incubation models. In seeking to address these changes at a regional and local level, a number of studies have suggested that the triple helix model (Academia, Industry and Regional government actors) should be extended to include the users of innovation as a fourth helix and 'multi focal lens' (Carayannis and Rakhmatullin, 2014:212). Users are seen as a specific stakeholder grouping with that of society (Carayannis and Campbell, 2009; Afonso et al., 2012), where the level of engagement of such users may vary (Arnkil et al., 2010) and is seen as playing a demand role within the incubation ecosystem and thus giving a commercial focus to the incubation process (Afonso et al., 2012). Moreover, Carayannis and Rakhmatullin (2014) suggest the need to classify stakeholder groupings that interact in a dynamic manner in producing innovative products for end users built upon regional strengths. In seeking to explore University incubation in this context it is thus suggested that stakeholder theory offers a unique perspective to probe the contextual nature of a region and its constituent university incubation models where the emphasis is on contextually grounded approaches as represented by different stakeholder groupings and their voices, tensions and synergies (Asheim and Coenen, 2005; Etzkowitz, et al., 2005; Plewa et al., 2013). However, when considering the role of stakeholders in incubation, there is a need to recognise that stakeholders may vary in accordance with region and university type. In addition, the strategy, culture, skills and knowledge of universities may all impact upon incubation models (HewittDundas, 2012).

Accordingly, the aim of this paper is to use a stakeholder lens to explore the development of University incubation models within unique regional and organisational characteristics and constraints. The paper commences with an overview of university incubation models and their subsequent adoption. Stakeholder theory is then used as the theoretical lens by which to analyse this adoption. The following section then presents the methodological rationale and method; which is subsequently followed by a critical evaluation of case study findings. Finally, the implications for theory and practice are considered.

\section{Regional University Incubation}

Over the past three decades, university incubation has emerged as a key contributor to regional economic growth (Corona et al., 2006). As a consequence, incubation models are seen as effective vehicles of job creation (Abetti, 2004) and as tools to initiate and revitalize industries and regions (Aaboen, 2009); thus emerging as one of "the mainstays of high technology industrial development' within regions" (Oakey, 2012: 67). Conceptually, university incubators connect science, technology, education, knowledge, entrepreneurial talent and capital (Smilor and Gill 1986; Mian, 1996; Aerts et al., 2007; Bergek and Norrman, 2008). They are embedded in a regional ecosystem composed of key stakeholders such as industrial clusters, universities, colleges, research laboratories, banks and investors. Thereby, incubators uniquely provide important links in the entrepreneurial value chain at a regional level (Phan et al., 2005). As hybrid organizations they are often established through collaboration amongst internal and external university stakeholders involved in university technology transfer activities, industry and governmental entities, and serve to promote technology transfer and diffusion into the local economy (Etzkowitz, et al., 2005; 2008). 
Traditionally, incubation models take the tangible format of a shared office space where nascent or University spin-out companies can avail of professional business support and advice, network provision and shared support services (Bergek and Norman 2008). However, in recent years, the viability of this approach has been questioned resulting in the evolution of incubation models to include virtual forms whereby nascent entrepreneurial firms can avail of incubation services without residing within a formalised incubation unit (Breznitz et al., 2008). This evolution of incubation models has been informed by a combination of the emergence of the knowledge economy (Smith and Zhang 2012), regional strategy and EU policy (Laursen, 2011). Indeed, examples of new and emerging incubation models include accelerators and technology trampolines which reflect a shift from tangible office space to more intangible, flexible and high value services which involve external knowledge capability building, experiential learning, networking and synergies (Grimaldi and Grandi, 2005; Bikfalvi et al., 2007; Criaco et al., 2013). In addition, recent emphasis on innovation strategies at the regional level (Rasmussen et al., 2013) and in particular Smart Specialisation-based regional innovation (Garcilazo et al., 2010; Camagni and Capello, 2013; McCann and Ortega-Argiles, 2013), have signalled a move away from universalist best practice approaches to incubation (Cooke et al., 2000; Asheim and Coenen, 2005). Indeed, business incubator models are increasingly seen as evolutionary, non-linear and interactive processes between various stakeholders in a regional context (Todtling and Trippl, 2005; Afonso et al., 2012; Carayannis and Rakhmatullin, 2014; Ivanova, 2014) where the model adopted is reflective of contextual factors. In seeking to define the relevant stakeholder groupings, we adopt and interpret the quadruple helix model from a stakeholder perspective consistent with Carayannis and Rakhmatullin (2014). Here university incubation is seen as embedded within the wider University Technology Transfer process involving academic entrepreneurs, Technology Transfer Office (TTO) staff, incubator staff, industry funders, regional Government policy makers and funders, and innovation users as suggested by Arnkil et al. (2010). Consequently, there has been a co-evolution of university incubation models as a result of negotiation and collaboration between stakeholders in a bid to enhance regional innovation (Miller et al., 2014) thus signalling a new generation of incubation models (Mian, 2011) which warrant further investigation.

Barca et al. (2012) and Camagni and Capello (2013) suggest that maximum engagement of all stakeholders involved in the quadruple helix model must be used to contextually ground regional innovation policy and practice. Place-based approaches to incubation highlight the maximum development of heterogeneous relationships between regional quadruple helix stakeholders in suggesting tailoring to the local context rather than externalised best practices (Garcilazo et al., 2010; Barca et al., 2012). Moreover, in a regional university context, there is a need to consider the impact of organisational and institutional arrangements, namely the meso environment on incubation processes (Barbosa and Faria, 2011; HewittDundas, 2012; Van Looy et al., 2011). However, within the current incubation literature, there are a lack of studies which explore the meso environment within which university incubation models are situated and consequently the impact of unique organisational and regional characteristics and constraints of quadruple helix stakeholders on University Incubation Models (Zahra and Wright, 2011; Barbosa and Faria, 2011; Rasmussen et al., 2014; Carayannis and Rakhmatullin, 2014). 


\section{Stakeholder Theory and Situated Regional Incubation}

Recent literature identifies the benefits of incubation model co-creation with multiple stakeholders as a means of sustainable competitive advantage (Chesbrough, 2011; Miller et al., 2014; Zahra et al., 2014). Extant research on incubation largely focuses on the 'process' of incubation (Galbraith and McAdam, 2013; Larsen, 2011; Hackett and Dilts, 2004) and consequently the challenges and suggested solutions on how to optimise growth within the micro environment of incubation has been referred to (Ahmad and Ingle, 2011). However, there is a lack of research and understanding of incubation models at the meso level. In the context of incubation, the meso environment encapsulates the myriad of relationships that take place between internal and external stakeholders as represented in the stakeholder interpretation of the quadruple helix model within unique organisational characteristics (i.e. culture, resources, and skills). Indeed, whilst the meso environment has its origins in economics (Baumol, 1968), the complex network of relationships and interactions of actors within regional incubation mechanisms which help bridge macro and micro systems is a neglected area of research despite its effect on innovation systems within regions (Doloreux and Parto, 2005; Swensson et al. 2012).

Prior to a discussion on the impact of quadruple helix stakeholders on regional incubation models, it is first necessary to define what is meant by a 'stakeholder'. According to Mitchel et al., (1997) an entity is considered to be a stakeholder if they have salience over the organisation. Mitchel et al.'s (1997) typology of stakeholder relationship attributes identifies that a stakeholder can gain or lose salience depending on their attributes. These attributes are: 1) power, which is the perceived ability of a stakeholder to influence organisational action; 2) legitimacy, which is perception of the stakeholders' actions as desirable, proper, or appropriate; and 3) urgency, which is the degree to which stakeholder claims are perceived to call for immediate attention (Friedman and Miles, 2002).

In order to aid an exploration of stakeholder relationships and the strategies stakeholders exert upon a firm, Frooman's (1999) resource-based dependency model is commonly referred to. According to Frooman (1999), the identification of the type of resource relationships between firms or business entities (i.e. in this context, between stakeholders and the university) is necessary in order to identify whether regional stakeholders can exert their influence on activities performed by the university. Resource relationships are a useful method of identifying levels of dependency or salience amongst stakeholders (Minoja, 2012; Miller et al., 2014), where the stakeholder groupings are consistent with that of the quadruple helix actors. Depending on the resource relationship a stakeholder may have over an organisation, they may decide to exert their power by using 'withholding' or 'usage' strategies (Frooman, 1999; McAdam et al., 2012). As noted by Miller et al., (2014), stakeholder relations do not necessarily follow a sequential path through each of the four stages of resource dependency as depicted by Frooman, (1999); rather they can adopt a series of dominant pathways which are dynamic resulting from changes in the power, influence and urgency of multiple quadruple helix stakeholder claims. Research by McAdam et al., (2012) and Miller et al., (2014) confirms that stakeholder resource relationships may go through a series of phases whereby stakeholders engage in an interactive process of negotiation and response to external factors within the incubation process. Accordingly, as shown in Figure 1, dominant pathways may exist which are bi-directional identifying the complex myriad of relationships organisations have with their stakeholders. 


\section{Insert Figure 1 about here}

\section{Conceptual Model and Research Questions}

In the context of regional incubation, Doloreaux and Parto (2005: 135) note that regional stakeholders and their interactions provide "rules, conventions and norms which prescribe behaviour and shape expectations". Consequently, these interactions, between the quadruple helix stakeholder groupings, will influence the incubation processes within a region and determine their success. However, as noted, stakeholder interactions are constrained by both regional and organisational factors to optimise Smart Specialisation-based regional innovation strategies (EU, 2012; Carayannis and Rakhmatullin, 2014). Figure 2 refers to the context of this research and demonstrates that incubation models within a region are influenced by 1 ) the macro environment, the situated regional context which dictates which stakeholders have salience and what resources are available for incubation. 2) The meso environment which recognises that organisational level factors, dictated by the university type (i.e. culture, mission, strategy, resources, skills, knowledge), will impact on the incubation model adopted. 3) The micro environment, which represents the actual incubation processes, which are embedded within the wider UTT process within a university. Incubation processes are often co-created as a result of stakeholder collaboration and interactions. The dotted arrows represent the influence various stakeholders' salience may have on the incubation processes.

\section{Insert Figure $\mathbf{2}$ about here}

Following the preceding discussion, the paucity of research within this area will be addressed through the exploration of the following research questions.

RQ1: What are the key university-stakeholder relationships, consistent with the stakeholder based quadruple helix model in relation to incubation processes within a peripheral region?

RQ2: What is the impact of organisational and institutional arrangements, namely the meso environment on university incubation models?

\section{Research Methodology}

This research aims to build theory in an under-researched aspect of incubation literature through the adoption of a stakeholder lens to explore the development of University incubation models within unique regional characteristics and constraints, and which takes account of regional University type. This approach reflects calls by Edquist (2005) who has noted that comparative studies exploring the regional context on innovation activities (including incubation models) to date has lacked both theoretical and empirical depth. Given the exploratory nature of this research, an interpretivist research approach has been adopted which uses an inductive theory building approach as suggested by Eisenhardt (1989) and Yin (2009). A qualitative methodology was deemed appropriate as it facilitates understanding of complex phenomena (Yin, 2009). As the aim was not to facilitate empirical generalisation but rather theoretical generalisation (Yin, 2009), a purposeful sampling strategy was deemed 
appropriate (Patton, 1990). Thus, the only two universities which were situated in a specified region, and so being exposed to the same quadruple helix stakeholder groups yet of varying types, were selected thus facilitating comparison across the cases as suggested by Van Looy et al. (2011) and are shown in Tables 1 and $2^{1}$. Cross-case analysis facilitates the comparison of commonalities and difference in the events, activities, and processes that are the units of analyses in case studies. Consequently, engaging in cross-case analysis is considered to extend the investigator's expertise beyond the single case (Yin, 2009). The case universities selected were of varying type; with one a research intensive, Russell Group University and the other a University UK group university. Both universities had a TTO and formal incubation processes however, the incubation models adopted were of varying type. Case 1 had a traditional physical on campus incubator whereas, Case 2 had a traditional physical incubator from 2001 to 2007, and a virtual incubator from 2007 to present day. The selection of these two cases of varying university type and varying incubation models was deemed meaningful given our aim of exploring University Incubation models within unique regional and organisational characteristics and constraints.

\section{Insert Table 1 and $\mathbf{2}$ about here}

As noted, incubation is embedded within the wider UTT process (Hisritch and Smilor, 1988), thus to fully explore university incubation models and how they are impacted by organisational contextual influences, there was a need to acknowledge these wider UTT processes due to their cumulative impact upon the incubation process. Therefore, in-depth interviews were carried out with multiple stakeholders involved in the UTT and incubation processes of the two universities within a peripheral region. A heterogeneous purposeful sampling strategy was followed in order to select respondents who were information rich (Patton, 2002) and consequently would be informative on the context under study. Table 3 identifies the respondents which took part in the study and their assigned codes.

\section{Insert Table 3 about here}

In addition, publically available documents were analysed relating to innovation and university incubation, in order to gain a holistic view of the area under study. These documents included governmental strategies and white papers and incubation case studies and documentation available from the regional universities websites. A method of open inductive coding (Miles and Huberman, 1994) was adopted which involved initial open coding of that which was deemed relevant in relation to our research aim and questions. These open codes were then synthesised into themes and subthemes through an iterative process of analysis and reflection through making use of 'theoretical coding' (Glaser, 1992:22) parallel to the collection of data. This iterative process of data analysis built up a chain of evidence by means of data triangulation from the interviews and documents (Cresswell, 2003; Saunders et al., 2007; Konecki, 2008); thus helping alleviate some of the limitations of lack of

\footnotetext{
${ }^{1}$ Qualitative and quantitative compiled data was collated from internal organisational reports and regional performance white papers.
} 
generalisation often associated with case study research (Kisfalvi, 2002). Appendix 1 illustrates how the open codes informed the themes and also provides additional excerpts of the narrative (Pratt, 2009) to substantiate these themes.

The rationale for undertaking this research within the context of a peripheral region in the North West periphery of Europe is due to the region's intrinsic characteristics (Stake, 2000). The region is on a border of a Eurozone country and until 2000 had Objective One Status ${ }^{2}$. In addition, the peripheral region is unique in that it has a separate distinct legal jurisdiction with its own local government which has devolved powers from the central government of the country. Consistent with prior research on peripheral regions (Doloreux, 2003; Todtling and Trippl, 2005; McAdam, 2014) it is characterised by low levels of R\&D (480 companies out of 80,000 involved in R\&D with BERD as $1 \%$ of GDP), a large SME base, a large public sector (63\% of GDP) and low scores on the EU, Innovation Scoreboard (DETI, 2014). Both the national and regional governments had placed a high emphasis on University technology transfer and incubation to offset these innate limitations and hence this regional context was selected as an appropriate case to examine the influence of context on University Incubation models.

\section{Findings}

The findings are presented in narrative form, using stakeholder constructs to identify the key quadruple helix-stakeholder relationships related to incubation in order to understand the implications of contextual factors on the incubation models of the two case universities. Table 4 summarises the key findings across the two case studies in relation to the key themes derived from the data analysis.

\section{Insert Table 4 about here}

\subsection{Regional Context}

As shown in Table 4, the empirical findings suggest that the funding mechanisms for incubation within the region influenced the incubation models of the two universities. As detailed in the methodology, this research took place in a peripheral UK region. Peripheral regions are known to face specific challenges due to their inherent characteristics (Harrison and Leitch, 2005; Harris et al., 2013). Many of the advantages cited in relation to being located in this region were related to the political history of the region which resulted in a devolved government from the rest of the country and as such, decisions related to regional development and consequently university incubation models were considered to be able to be made more effectively and expediently than in other parts of the country. As a consequence, the core stakeholders who governed incubation differed from the stakeholders which governed incubation processes within more central regions. A core stakeholder within the case region was the Regional Development Agency. In contrast, in central regions, local enterprise partnerships replaced regional development agencies in 2010 and subsequently follow a different funding model whereby regions are required to submit bids to an annual f1.4 billion regional growth fund on a competitive basis (BIS, 2012; McAdam et al., 2012). The

\footnotetext{
${ }^{2}$ Objective 1 aims to help reduce differences in social and economic conditions within the European Union, where prosperity, measured in Gross Domestic Product (GDP), was 75\% or less of the European average.
} 
differences in these funding mechanisms was said to be of benefit for the two case universities due to easier access to public funding for incubation activities as a result of less competition compared to the central region (Table 2 identifies HEIF funding allocated). C1TTO1 who had previously worked in other regions within the country had stated his surprise at how much funding and interventions the region had for university incubation activities. However, as this money originated from government initiatives, government had the power to direct the structure and outcome of incubation by withholding funding or attaching conditions against how funding should be used. C1IS1 commented, "XX seem to want more spin outs so that's what will get if the funding is there". This reliance on government support for incubation was evident and as such, many technologies often failed to obtain alternative funding to take their products to market. This difficulty was seen as a "vicious circle" (С2TTO3) of relying on state funding. It was noted by the incubator staff that both universities could spin out companies without help from the government but that such financial support was crucial in terms of longevity and progression beyond the incubation stage of development.

It was also noted that government funding for university incubation was increasingly being linked to universities' ability to engage with end users and industry and so driving the need for both universities to develop their incubation models. Interestingly, one of the core challenges identified by the interviewees related to the large number and diversity of government stakeholders, all with funding for incubation and university spin-outs. Hence, a reoccurring theme of the challenges of balancing multiple stakeholders' objectives in the incubation process was evident. C2S identified that often the only way to get diverse stakeholder's to collaborate in harmony was mutual monetary benefits. "People will collaborate when it is in their interest. Successful collaboration is not based on altruism...money for research collaboration is always a driver" (CS2).In addition to this, it was often difficult to identify the most salient stakeholders. One of the core roles of the TTO and incubator staff in both universities was to help signpost principal investigators (PIs) to the most salient stakeholders in relation to aiding incubation, who were often sector specific. However, some of the PIs felt that the TTO did not have the knowledge and skills to bridge relations between regional stakeholders "As for connection to companies and potential markets, it is unlikely that XXX with have the necessary technical skills or the necessary technical marketing skills in there, I'm sorry. So therefore we have to do that work so what are they doing? The only thing they are doing is the agreement that sets up the company" (C2PI3).It was noted by all the interviewees within both universities that better stakeholder co-ordination within the region was needed to aid transparency and improve the efficiency of incubation processes.

It also emerged that locational factors of being in a peripheral region caused challenges in relation to engaging more fully with industry and end users to enhance incubation. For example, within Case 2, many PIs identified that being located in a peripheral region did make networking with large companies difficult as larger companies tended to locate in more central regions. They commented that travelling to international conferences and events in order to meet the "big players in your sector" was essential (C2PI4). It was also identified that it was difficult to find the time and resources to constantly network with industry. This was particularly evident in Case 1, where their university remit meant that PIs had limited time 
and resources to invest in networking with industry and end users. Whilst in Case 1, it was thought that the university brand of being a research university alongside academics having an international track record for publications in the sector helped to counteract locational factors (Table 2 identifies Case 1's success in research activities and income generation). For example, C1PI1 remarked "we have been contacted by a couple of big names who had heard about our research as a result of our publications and have in fact visited the incubator".

\subsection{Stakeholder Relationships and incubation}

As shown in Table 4, the increasing need to collaborate more with quadruple stakeholders and the challenges of developing stakeholder relationships influenced the incubation models of both universities. C1IS1 noted, "you have multiple stakeholders, all of which want reporting metrics, a surprising number of them being mutually exclusive. It's the nature of the beast". Indeed that the need to balance the needs of high salience internal university stakeholders alongside the need to engage more fully with government industry and end users shaped the incubation models of each university.

White papers and governmental strategy reports (e.g. DETNI, 2011) identified the need for technology commercialisation and incubation efforts to become more co-creational. From the interviews, it was evident that there was tension felt by Case 2 in relation to the power that government agencies had over the incubation process. "They have the programmes, they have the time frames, they have their spend profiles and they are driven by those targets but it might not fit with the timetable that we have because we might need money to get that person working on it in the next month" (C2IS2). Indeed, the adoption of collaborative best incubation practices from other regions and in particular practices used in the neighbouring region was identified; however this approach required significant investments through additional public funding further intensifying the salience government had over the incubation processes in the region. As such, there was considerable doubt placed on whether interdependence, which is a perquisite of an effective quadruple helix, would ever be achieved due to evident dependency both universities had on government- funding. "I suppose there is a risk of a dependency ......., organisations that are putting the funding in place and ideally you're looking for that situation, that sort of industry and academia and government all working in collaboration, which is easy to say and harder to do" (C1S).

It was evident that relations between quadruple stakeholders in the region were undergoing a stage of transition. Both universities recognised the importance of collaborative relationships with industry and end users in order to enhance incubation success however, the institutional and organisational context was found to influence the salience attributed to quadruple helix stakeholders and consequently impacted the incubation model adopted which will be discussed under the next theme.

\subsection{Institutional and organizational context}

It was evident from both the interviews and document analysis and as seen in Tables 1 and 2, that both universities were of varying type and thus it was identified that their different organisational cultures and values influenced the incubation models adopted. This diversity 
reflected the differences in organisational structure between the two cases which was reflected in their respective Academic Enterprise Strategies. For instance, in Case 1, which was a research intensive university, the emphasis on the Research Exercise Framework (REF) often meant that publications and impact case studies were deemed more valuable than the creation of a spin-out company for both the academic and institution. Despite this, Case 1 was considered more successful at spin out generation than Case 2 (see Table 2), suggesting the importance of a vast portfolio of research for economic development. This was emphasized by C1PI2 who identified the benefit of high quality publications to aid connections with industry and end users to aid incubation success. "We have been lucky, I guess it's down to the fact we have numerous publications in our field and had built up a bit of a reputation as experts in our discipline". However, it was thought that the promotion mechanisms which emphasised research as opposed to academic enterprise in Case 1 often led to missed opportunities for additional commercialisation, enhancing job creation and revenue generation within the region. Pl's in Case 1 cited the challenge of balancing the need to devote significant time to publishing and obtaining research funding as a means of promotion and their ability to engage with Quadruple helix stakeholders. Whilst many PIs recognised the benefits which could be accrued from wider engagement with industry and end users, the internal culture of the university meant that industry and end users were not seen as high salience stakeholders thus a lack of time and resources were attributed to developing quadruple helix stakeholder relationships. This challenge was also recognised by the incubator staff and was said to impact upon the incubation models adopted. "Academic publications run directly counter to the commercialisation task. That is one of the great ironies at the heart of the academic research system!" (C1ISM).

In sharp contrast, it was noted that the variances in internal promotional mechanisms in Case 2 helped facilitate greater connections with business through a wide range of engagement activities such as knowledge transfer partnerships, consultancy, seminar series etc. (see Table 1). In order to facilitate engagement with such activities, Case 2's incubation model had moved away from the traditional standalone incubator model towards a virtual incubation model whose support services were embedded throughout its academic enterprise activities as opposed to being housed in a standalone entity. Indeed, it was identified by C2S that plans had recently been approved to merge the research and enterprise department with the TTO which would lead to a more streamlined process in relation to linking research projects to university incubation models in a bid to enhance incubation success. It was identified by both C1S and C2S that the focus of impact in REF has meant that a large amount of the funding that Research Councils would have issued for basic research will now require more of an industry focus. As such there will be an even greater need to consider the practical application of research from the beginning of a research project suggesting that Case 2's strengths with industry engagement combined with their more flexible incubation processes may accrue advantages over Case 1 in the future. GOV2 identified that Case 1 had different challenges to Case 2 as a result of their enterprise strategies however, it was thought that the strengths and weaknesses of both universities "evens itself out" (GOV2) in contributing to the overall incubation agenda within the region.

\subsection{Incubation Models}


As noted, the incubation processes and outcomes were often dictated by the stakeholders who were funding the technology. C1IS1 commented, "You go with what the funders want. At the moment XX (government) seem to want spin out companies and they're providing a lot of the money so spinout companies are very much an option". Despite sharing the same overall aim, it was evident that there were variances in the incubation models adopted by each university in order to achieve this aim which were dictated by their respective institutional and organisation contexts (as shown in Table 4). As pointed out by Aaboen (2009), differences between incubators in terms of their objectives are in part dictated by the types of spin-outs they cater for. Indeed, as C2IS2 remarked "spins out from arts and computing can be spun out fairly quickly so they don't need the long incubation time say that a pharmaceutical spinout would require".

According to Carayannis and Von Zedtwitz (2005), the support structure provided by an incubator can either be a strict or a loose interpretation of the term. Case 1's traditional oncampus university incubator was strict in the sense that it provided hot-desking facilities, small meeting rooms and a shared environment where people could meet and network. The PIs in Case 1 agreed that the on campus incubator was an effective model to help them escape the academic remit and research expectations required from a research intensive university. "It's very hard to do the business thoughts in your day job, in your office, because you've got all the distractions of normal work. You need somewhere else for people to come and hence provide the incubator because it's a different environment where there are other people in there doing commercial work, not grant research" (C1PI2).

However, as mentioned since 2007 Case 2 had moved from an on-campus physical model to a virtual incubation model. This adoption was in keeping with the university's academic enterprise strategy which emphasized close engagement with industry and end users. The virtual incubation model was run by the TTO and often university spin-out companies were located within the faculties and departments on campus which allowed PIs to access key technologies and resources whilst still resuming their academic duties. The virtual incubator was said to not only be cost effective but C2ISM stressed that the tacit and intangible elements of incubation were of greatest importance. "If you have a nice fancy building in the centre....you need to cover your rent but creating these virtual incubators in office space, it is not costing them" (C2ISM). Importantly, Case 2's virtual incubator was complemented by the internal structure of the university which facilitated interaction and networking between disciplines and new business start-ups. For example, cross-disciplinary seminars and events where PI showcased their technologies was an effective way for the PIs to network with other start-ups and industry and end users. Furthermore, Case 2 developed a virtual community which facilitated knowledge transfer and networking. Near the end of the research period, Case 2 had implemented an open IP policy which allowed industry and end users to try technologies before investment. This was expected to further develop relationships with industry and end users and overcome IP issues which in the past have been found to prevent industry and end user collaboration in the incubation process. 


\section{Discussion}

From the analysis of the findings it was evident that the regional and organisational contexts of the two universities were found to impact upon the incubation models adopted. Concurring with prior research (Amoros et al., 2013; Harris et al., 2013; McAdam et al., 2014; Varis et al., 2014), being located within a peripheral region was considered to have both advantages and disadvantages. The peripheral region under study had a devolved government which was said to lead to faster decision making and easier access to public funding for incubation activities due to less competition compared to the central region. However, as noted by McAdam et al. (2012) the emergence of local enterprise partnerships in other regions was aimed at encouraging university incubation models to become more selfsufficient. Indeed, the findings suggested that the peripheral region was experiencing a resource dependency issue (Frooman, 1999; Miller et al, 2014) in relation to government support for incubation processes in comparison to more central regions. Referring to Figure, 1 and drawing upon Mitchell et al. (1997) and Frooman (1999) government were seen to have stakeholder power, legitimacy and urgency therefore had high salience over the incubation activities of both universities. Furthermore concurring with Miller et al., (2014) it was reported that government had the power and legitimacy to use withholding and usage strategies (Frooman, 1999) in relation to the funding they provided for incubation activities in the two universities. It was noted by the TTOs that both universities could spin out companies without help from the government but that such financial support was crucial in terms of longevity and progression beyond the incubation stage of development. As such, the peripheral region was considered to be in a constant stage of government (stakeholder) power (Frooman, 1999; Mitchell et al., 1997) as seen in Figure 1, due to the provisions of state funding needed for incubation within both universities. These empirical findings provide new insights as to the influence high salience stakeholders on incubation models (Hackett and Dilts, 2004; Alsos et al., 2011) and questions regional policy which dictates that incubation should involve co-creational models where government, industry, end users and universities interact interdependently (Ivanova, 2014; Carayannis and Rakhmatullin 2014; RIS, 2014). Prior research identifies that power relationships will always exist when stakeholders are engaged in resource relationships (Frooman, 1999; Mitchell et al., 1997; McAdam et al., 2012; Miller et al., 2014). Consequently, there is a need for mechanisms to ensure stakeholders can reach a stage of high interdependence involving symmetrical net exchanges of resources to support incubation (Frooman, 1999; McAdam et al., 2012).

Building on research by McAdam et al., (2014) and Harris et al., (2013) and as detailed in Table 4 , the findings identified that incubation and new start-up schemes in central regions were slow to roll out into the peripheral region due to its geographic location questioning the equity of incubation support between central and peripheral regions. Furthermore, the physical location of the region (Boschma, 2005; Varis et al., 2014; McAdam et al., 2014) was found to reduce the visibility of early stage embryonic technologies to potential funders and international industry partners. This provides new insights into the ability of peripheral regions to embrace quadruple helix structures (as dictated by recent innovation policy, RIS, 2014) within incubation models, where geographical factors impact universities ability to interact with industry and end users (Larsen et al., 2011). 
It was evident from both the interviews and document analysis and as seen in Tables 1 and 2, that both universities were of varying type and thus their different organisational cultures, values and resources evidently affected their incubation models (Hewitt-Dundas, 2012; Van Looy et al., 2011). Accordingly the support structure offered by Case 1 was in the form of the traditional physical incubator, however, it was identified that there was a mismatch between the REF remit and the incubator ethos of supporting academic enterprise. This sheds new light on the need to align internal initiatives in order to promote engagement with quadruple helix stakeholders throughout the UTT process to enhance technology commercialization (Alsos et al., 2011). In contrast, Case's 2 incubation support was loose in the sense that it was virtual in nature (Carayannis and Von Zedtwitz, 2005). This looseness and flexibility which the virtual model provided aligned with the flexible remit of its academic staff which encouraged engagement with industry and end users in addition to the specific needs of the disciplines within the university. Furthermore the virtual incubation community which evolved in tandem served as an alternative support mechanism facilitating networking with other incubatees, industry and end users. This finding concurs with Grimaldi and Grandi, (2005) and sheds light on the different types of incubation models universities can adopt based on organizational factors.

\section{Conclusion}

The aim of this paper was to use a stakeholder lens to explore University Incubation models within unique regional and organisational characteristics and constraints. From the findings of this exploratory study, it is concluded that variances existed in relation to the two universities incubation models which were found to result from both regional (macro environment) and organisational (meso environment) influences (i.e. university type). It was found that governance stakeholders of incubation processes within the peripheral region under study were different from those in more central regions of the country. The provision of regional development agencies which have interventions and funding available for university incubation activities, combined with the inherent characteristics of the region (i.e. low innovation index, low R\&D, large SME base, large public sector, location) meant that both universities were reliant on public funding. Consequently, government had stakeholder power (Frooman, 1999) and as such were exerting their salience through withholding and usage strategies and consequently influencing incubation models. This situation is in contrast to recent policy which identifies the need for regional quadruple helix stakeholders to work in collaboration to reach a stage of high interdependence (Frooman, 1999) to help co-create innovative ecosystems and consequently enhance regional development (McAdam et al., 2012; Miller et al., 2014).

In addition, it was evident that variances existed in the incubation processes across the two universities. This was found to be influenced by their corresponding culture, internal mechanisms and engagement with quadruple helix stakeholders. Indeed, Case 1 adopted a traditional incubator model whereas Case 2 prescribed to a virtual incubator model which was said to meet the flexible remit and requirements of technologies disclosed. These findings give rise to the premise that incubation should consider organisational characteristics i.e. university type questioning the validity of generic best practice approaches to incubation within countries and also within regions. With universities increasingly viewed as engines of economic growth through technology transfer and commercialization of research results, this 
research stresses the need for a regionally and contextually integrated technology incubation model in order to nurturing and growing such enterprises (Smith and Zhang, 2012; Zahra et al., 2014).

In this paper we make the following contributions. First, we contribute to incubation theory by providing empirical evidence of the influencing role of the regional context in influencing incubation models. Second as a result of our comparative analysis we highlight the role of university type (meso environment) and subsequent culture, research strategy and disciplines in influencing the incubation model adopted. Third, we advance incubation theorising by identifying the role of quadruple helix stakeholders in challenging traditional university incubation models. Fourth, from a practitioner viewpoint, we provide insights into the need for appropriate design and tailoring of university incubation models (via acknowledgment of quadruple helix stakeholder influence) to incorporate contextual influences rather than adopting a best practice approach.

This research was carried out within a peripheral region using a comparative case study methodology. It is widely recognised that case study research does not lend itself to empirical generalizability (Yin, 2009). However, the aim of this study was not to facilitate replicability but rather theoretical generalisation (Yin, 2009) in the provision of conceptualisations and understanding as to how future research on incubation models needs to consider organisational and regional characteristics and constraints. Indeed, it is our intention that the use of stakeholder constructs can be reinterpreted and reconstructed in other contexts to explore how quadruple helix stakeholders interact and engage shape Incubation models (Eisenhardt, 1989). Accordingly, it is posited that further research is needed to aid theory development and refinement in other regional contexts. In particular, research should explore the role of high salience stakeholders in co-creating incubation models to meet unique regional and organisational needs. Furthermore, future research should identify the challenges of universities implementing more end user engagement into their incubation models. Moreover, future research should avail of a larger number of constituent Universities of varying types and so developed into testable propositions using survey data of universities in multiple regions to add to empirical generalisation.

\section{References}

Aaboen, L. (2009) Explaining incubators using firm analogy. Technovation, 29 (10), 657-670. Abetta, P. A. (2004) Government-Supported Incubators in the Helsinki Region, Finland: Infrastructures, Results and Best Practices. The Journal of Technology Transfer, 29 (1), 19-40. Aerts, K., Matthyssens, P. and Vandenbempt, K. (2007) Critical role and screening practices of European business incubators. Technovation, 27 (5), 254-267.

Afonso, O., Monteiro, S. and Thompson, M. (2012) A growth model for the quadruple helix. Journal of Business Economics and Management, 13(5), 849-865.

Ahmad, A.J. and Ingle, S. (2011) Relationships matter: Case study of a university campus incubator. International Journal of Entrepreneurial Behaviour and Research, 17 (6), 626-644. Allen, D.N. and Rahman, S. (1985) Small business incubators: A positive environment for entrepreneurship. Journal of Small Business Management, 23 (3), 12-22. 
Amorós, J.E. Felzenstein, C., and Gimmon, E. (2013) Entrepreneurial opportunities in peripheral versus core regions in Chile. Small Business Economics, 40, 119-139.

Arnkil, R. and Jarvensivu, V., Koski, P. and Pijrainen, T. (2010) Exploring Quadruple Helix. Outlining User-orientated innovation models. Working paper, University of Tampere, Institute for Social research, Work research Centre.

Asheim, B.T. and Coenen, L. (2005) Knowledge bases and regional innovation systems: comparing Nordic clusters. Research Policy, 34 (8), 1173-90.

Barbosa, N. Faria, A.P. (2011) Innovation across Europe: How important are institutional differences?_Research Policy, 40 (9), 1157-1169.

Barca, F., McCann, P. and Rodríguez-Pose, A. (2012) The case for regional development intervention: Place-based versus place-neutral approaches. Journal of Regional Science, 52 (1), 134-152.

Baumol, W. J. (1968) Entrepreneurship in economic theory. American Economic Review, 58 (2), 64-71

Bergek, A. and Norrman, C. (2008) Incubator best practice: A framework. Technovation, 28 (1-2), 20-28.

Bikfalvi, A., Seralos, C., Urbano, D. and Vaillant, Y. (2007) Technological trampolines for new venture creation in Catalonia: the case of university of Girona. Working paper, Available at: http://www.uab.cat/servlet/BlobServer?blobtable=Document\&blobcol=urldocument\&blob header=application/pdf\&blobkey=id\&blobwhere=1345650660635\&blobnocache=true (30/05/15).

BIS, (2012) Annual Innovation Report 2912. Innovation, research and growth. Available online:

https://www.gov.uk/government/uploads/system/uploads/attachment data/file/34805/12 -p188-annual-innovation-report-2012.pdf (accessed 07/03/14)

Boschma, R.A. (2005) Proximity and Innovation, A critical Assessment. Regional Studies, 39 (1), 61074.

Breznitz, S. M., O'Shea, R. and Allen, T. J. (2008) University commercialization strategies in the development of regional bio clusters. Journal of Product Innovation Management, 25 (2), 129142.

Camagni, R. and Capello, R. (2013) Regional Innovation Patterns and the EU Regional Policy Reform: Toward Smart Innovation Policies. Growth and Change, 44 (2), 355-389.

Carayannis, EG, \& Von Zedtwitz, M (2005). Architecting gloCal (global-local), real-virtual incubator networks (G-RVINs) as catalysts and accelerators of entrepreneurship in transitioning and developing economies: lessons learned and best practices from current development and business incubation practices. Technovation, 25(2), 95-110

Carayannis, E.G. and Campbell, D.F.J. (2009) Mode 3' and 'Quadruple Helix': toward a 21st century fractal innovation ecosystem. International Journal of Technology Management, 46(3-4), 201-234.

Carayannis, E.G. and Rakhmatullin, R. (2014) The Quadruple/Quintuple Innovation Helixes and Smart Specialisation Strategies for Sustainable and Inclusive Growth in Europe and Beyond. Journal of the Knowledge Economy, 5(2), 212-239.

Chesbrough, H. (2011) Bringing open innovation to services. MIT Sloan Management Review, $52,85-91$.

Cooke, P., Boekholt, P. and Tödtling, F. (2000) The Governance of Innovation in Europe: Regional Perspectives on Global Competitiveness. Pinter, London. 
Corona, L., Doutriaux, J. and Mian, S. (2006) Building Knowledge Regions in North America: Emerging Technology Innovation Poles. Cheltenham, Edward Elgar.

Creswell, J.W. (2003) Research Design: Qualitative, Quantitative and Mixed Methods Approaches, 2nd ed. London, Sage.

Criaco, G., Minola, T., Migliorini, P., Serarols, C., 2013. "To Have and Have Not": Founders' Human Capital and University Start-up Survival. Journal of Technology Transfer, 39 (4), 567593.

Daskalopoulou, I., Liargovas, P. and Petrou, A. (2010). A comparative study of business incubators and technoparks in the EU. International Journal of Innovation and Regional Development, 2 (3), 198-220.

DETI, (2014) Regional Innovation Scoreboard 2014. Available online: http://ec.europa.eu/enterprise/policies/innovation/files/ius/ius-2014 en.pdf (accessed 07/03/2014)

DETNI, (2011) UK Innovation Survey 2011: Northern Ireland. Available online: http://www.detini.gov.uk/uk innovation survey 2011 ni results.pdf $\quad$ (accessed 07/03/2014).

Doloreux, D. (2003) Regional innovation systems in the periphery: the case of the Beauce in Québec (Canada). International Journal of Innovation Management, 7 (1), 67-94.

Doloreux and Parto, S. (2005) Regional innovation systems: Current discourse and unresolved issues. Technology in Society, 27 (2), 133-153.

Edquist, C. (2005) Systems of innovation - Perspectives and challenges. In Fagerberg, J., Mowery, D.C. and Nelson, R.R. (Eds.), The Oxford handbook of innovation. Oxford University Press. Oxford.

Eisenhardt, K. M. (1989) Building Theories from Case Study Research. The Academy of Management Review, 14 (4), 532-550.

Etzkowitz, H., Mello, J.M.C., Almeida, M. (2005) Towards "meta-innovation" in Brazil: The evolution of the incubator and the emergence of a triple helix. Research Policy, 34 (4), 411 424.

Etzkowitz, H. (2008) The Triple Helix: University-Industry Government in action. Routledge, London

EU (2012) Regional policy, http://ec.europa.eu.

Fogelberg, H. and Sandén, B.A. (2008) Understanding reflexive systems of innovation: An analysis of Swedish nanotechnology discourse and organization. Technology Analysis and Strategic Management, 20 (1), $65-81$.

Friedman, A.L. and Miles, S. (2002) Developing stakeholder theory. Journal of Management Studies, 39 (1), 1-21.

Frooman, J. (1999) Stakeholder influence strategies. Academy of Management Review, 24 (2), 191-205.

Galbraith, B. and McAdam, R. (2013) The convergence of ICT, policy, intermediaries and society for technology transfer: evidence from European innovation projects. Technology Analysis and Strategic Management, 25 (3), 249-252.

Garcilazo, E., Oliveira Martins, J., and Tompson, W. (2010) Why Policies May Need to be PlaceBased in Order to be People-Centred, OECD Regional Development Policy Division, Paris. Available online at: http://www.voxeu.org/ (accessed 24/03/2014).

Garrett-Jones, S., Turpin, T., Burns, P. and Diment, K. (2005) Common purpose and divided loyalties: the risks and rewards of cross-sector collaboration for academic and government researchers. R\&D Management, 35 (5), 535-44. 
Glaser, B. (1992) Basics of Grounded Theory Analysis. Mill Valley, CA: Sociology Press. Grimaldi, R. and Grandi, A. (2005) Business incubators and new venture creation: an assessment of incubating models. Technovation, 25 (2): 111-121

Hackett, S. M. and Dilts, D.M. (2008) Inside the black box of business incubation: Study B Scale assessment, model refinement, and incubation outcomes. The Journal of Technology Transfer, 33 (5), 439-471.

Hackett, S. M. and Dilts, D. M. (2004) A real options-driven theory of business incubation. The Journal of Technology Transfer, 29 (1), 41-54.

Harris, R., McAdam, R., McCausland, I. and Reid, R. (2013) Levels of innovation within SMEs in peripheral regions: the role of business improvement initiatives. Journal of Small Business and Enterprise Development, 20 (1), 102-124

Harrison, R.T. and Leitch, C.M. (2005) Entrepreneurial learning: Researching the interface between learning and the entrepreneurial context. Entrepreneurship Theory and Practice, 29 (4), 351-371

Hewitt-Dundas, N. (2012) Research intensity and knowledge transfer activity in UK Universities. Research Policy, 41 (2), 262-275

Hisritch, R.D. and Smilor, R.W. (1988) The university and business incubation: Technology transfer through entrepreneurial development. Journal of Technology Transfer, 13(1), 14-19. Howells, J. Ramlogan, R. and Cheng, S.L. (2012) Innovation and University collaboration: paradox and complexity within the knowledge economy. Cambridge Journal of Economics, 36 (3), 703-721.

Ivanova, I. (2014) Quadruple Helix Systems and Symmetry: a Step towards Helix Innovation System Classification. Journal of the Knowledge Economy, 5(2), 357-369.

Kisfalvi, V. (2002) The entrepreneurs character, life issues and strategic making: a field study. Journal of Business Venturing, 17 (5), 489-518.

Konecki, K.T. (2008) Triangulation and dealing with the realness of qualitative research. Qualitative Sociology Review, 4 (3), 7-28.

Larsen, G. (2011) Understanding the early stages of the innovation diffusion process: awareness, influence and communication networks. Construction Management and Economics, 29 (10). 987-1002.

Laursen, K. Reichstein, T. Salter, A. (2011) Exploring the effect of geographical proximity and university quality on university-industry collaboration in the United Kingdom, Regional Studies, 45(4), 507-523.

Lewis, D. A. (2001) Does technology incubation work? A Critical Review. Reviews of Economic Development Literature and Practice. U.S. Economic Development Administration, Dep. of Commerce No: Issue Washington D. C.

Liargovas, P. (2013) Do Business Incubators and Technoparks affect Regional Innovation? A comparative study in the EU27 and the NC1 countries. Working Paper. Available online: http://www.ub.edu/searchproject/wp-content/uploads/2013/01/WP-4.5.pdf Iaccessed 27/03/14).

McAdam, R., Miller, K., McAdam, M. and Teague, S (2012) The development of University Technology Transfer stakeholder relationships at a regional level: lessons for the future. Technovation, 32 (1), 57-67.

McAdam, R. (2014) Determinants for innovation implementation at SME and inter SME levels within peripheral regions. International Journal of Entrepreneurial Behaviour \& Research, 20 (1), 66-90. 
McCann, P. and Ortega-Argilés, R. (2013) Transforming European regional policy: a resultsdriven agenda and smart specialization. Oxford Review of Economic Policy, 29 (2), 405-431. Mian, S. (2011) Science and Technology Based Regional Entrepreneurship: Global Experience in Policy and Program Development. Cheltenham, Edward Elgar Publishers.

Mian, S. (1996) The university technology incubator: a strategy for developing research/ technology-based firms. Journal of High Technology Management Research, 7 (2), 191-208. Miles, M.B. and Huberman, A.M. (1994) Qualitative Data Analysis. Thousand Oaks, CA: Sage Publishing.

Miller, K., McAdam, M. and McAdam, R. (2014) The University Business Model: Evolution and Emergence from a Stakeholder Perspective. R\&D Management, 44(3), 265-287.

Minoja, M. (2012) Stakeholder Management Theory, Firm Strategy, and Ambidexterity. Journal of Business Ethics, 109 (1), 67-82.

Mitchell, R. K., Agle, B. R. and Wood, D. J. (1997) Toward a Theory of Stakeholder Identification and Salience: Defining the Principle of Who and What Really Counts. The Academy of Management Review, 22 (4), 853-886.

Oakey R. P., Groen A., Cook P. and van der Sijde P. (2012) New Technology-based Firms in the New Millennium, Vol. IX. High Technology-based firms in the New Millennium. Bingley, Yorks, England.

Patton, M.Q. (2002) Qualitative Research and Evaluation Methods. Thousand Oaks, CA, Sage. Phan, P. H., Siegel, D.S. and Wright, M. (2005) Science parks and incubators: observations, synthesis and future research. Journal of Business Venturing, 20 (2), 165-182.

Plewa, C., Rampersad, G., Johnson, C.R., Baaken, T., MacPherson, G. and Korff, N. (2013). The evolution of university-industry linkages-A framework. Journal of Engineering and Technology Management, 30 (1), 21-44.

Pratt, M. (2009). For the Lack of a Boilerplate: Tips on Writing up (And Reviewing) Qualitative Research. Academy of Management Journal, 52(5): 856-862.

Rasmussen E, Mosey S, Wright, M. (2014) The influence of university departments on the evolution of entrepreneurial competencies in spin-off ventures. Research Policy, 43 (1), 92106.

Saunders, M., Lewis, P. and Thornhill, A. (2007) Research Methods for Business Students, 4th ed. London: Prentice Hall.

Smilor, R. and Gill, M. (1986) The new business incubator: Linking talent, technology and knowhow. Massachusetts: Lexington Books.

Smith, D.J. and Zhang, M. (2012) The Evolution of the Incubator Concept. International Journal of Entrepreneurship and Innovation, 13 (4), 227-234.

Stake, R.E. (2000) Case studies. In: Denzin, N.K. and Lincoln, Y.S. (eds), Handbook of Qualitative Research, 2nd ed. Thousand Oaks, CA: Sage Publications.

Swensson, P. Klofsten, M. and Etzkowitz, H. (2012) An entrepreneurial university strategy for renewing a declining industrial city: The Norrkoping Way, European Planning Studies, 20(4), 505-525.

Tamasy, C. (2007). Rethinking technology-oriented business incubators: developing a robust policy instrument for entrepreneurship, innovation and regional development? Growth and Change, 38 (3), 460-473.

Tödtling, F. and Trippl, M. (2005) One size fits all? Towards a differentiated regional innovation policy approach. Research Policy, 34 (1), 1023-1209. 
Van Looy, B., Landoni, P., Callaert, J., van Pottelsberghe, B., Sapsalis, E. and Debackere, K. (2011) Entrepreneurial effectiveness of European universities: An empirical assessment of antecedents and trade-offs. Research Policy, 40 (4), 553-564.

Varis, M. Tohmo, T. and Litunen, H. (2014) Arriving at the dawn of the new economy: Is knowledge-based industrial renewal possible in a peripheral region? European Planning Studies, 22 (1), 101-125.

Voisey, P. L. Gornall, P. Jones, and B. Thomas (2006) The Measurement of Success in a Business Incubation Project. Journal of Small Business and Enterprise Development, 13 (3), 454-468.

Wonglimpiyarat, J. (2010) Commercialization strategies of technology: lessons from Silicon Valley. Journal of Technology Transfer, 35 (2), 225-36.

Yin, R.K. (2009) Case Study Research: Design and Methods. Thousand Oaks, CA, Sage.

Zahra SA and Wright M (2011) Entrepreneurship's next act. Academy of Management Perspectives, 25(4), 67-83

Zahra, S.A. Wright, M. and Abdelgawad, G. (2014) Contextualisation and Advancement of Entrepreneurship Research. International Small Business Journal, 32(5), 479-500.

Figure 1: Dynamic dominant pathways of stakeholder resource relationships. Source: Miller et al., (2014)

\begin{tabular}{|c|c|c|}
\hline & No & Yes \\
\hline $\begin{array}{l}\text { No } \\
\text { Is the university } \\
\text { dependent } \\
\text { upon the }\end{array}$ & $\begin{array}{l}\text { Low interdependence } \\
\text { Indirect/Withholding strategies } \\
\text { Both stakeholder and university } \\
\text { have low power, legitimacy } \\
\text { urgency } \\
\text { Symmetrical net exchange unlikeli } \\
\text { to exert salience }\end{array}$ & $\begin{array}{l}\text { University power } \\
\text { Indirect/Usage strategies } \\
\text { University has power, legitimacy } \\
\text { to exert alience }\end{array}$ \\
\hline Yes & $\begin{array}{l}\text { Stakeholder power } \\
\text { Direct/Withholding strategijact } \\
\text { Stakeholder has power, legitimacy } \\
\text { and urgency } \\
\text { Asymmetrical net exchange - likely } \\
\text { to exert salience }\end{array}$ & $\begin{array}{l}\text { Dither Interdependence } \\
\text { Both stakeholder and university } \\
\text { have high power, legitimacy and } \\
\text { urgency } \\
\text { Symmetrical net exchange -unlikely } \\
\text { to exert salience }\end{array}$ \\
\hline
\end{tabular}


Figure 2: Context of study: Influences on the incubation model

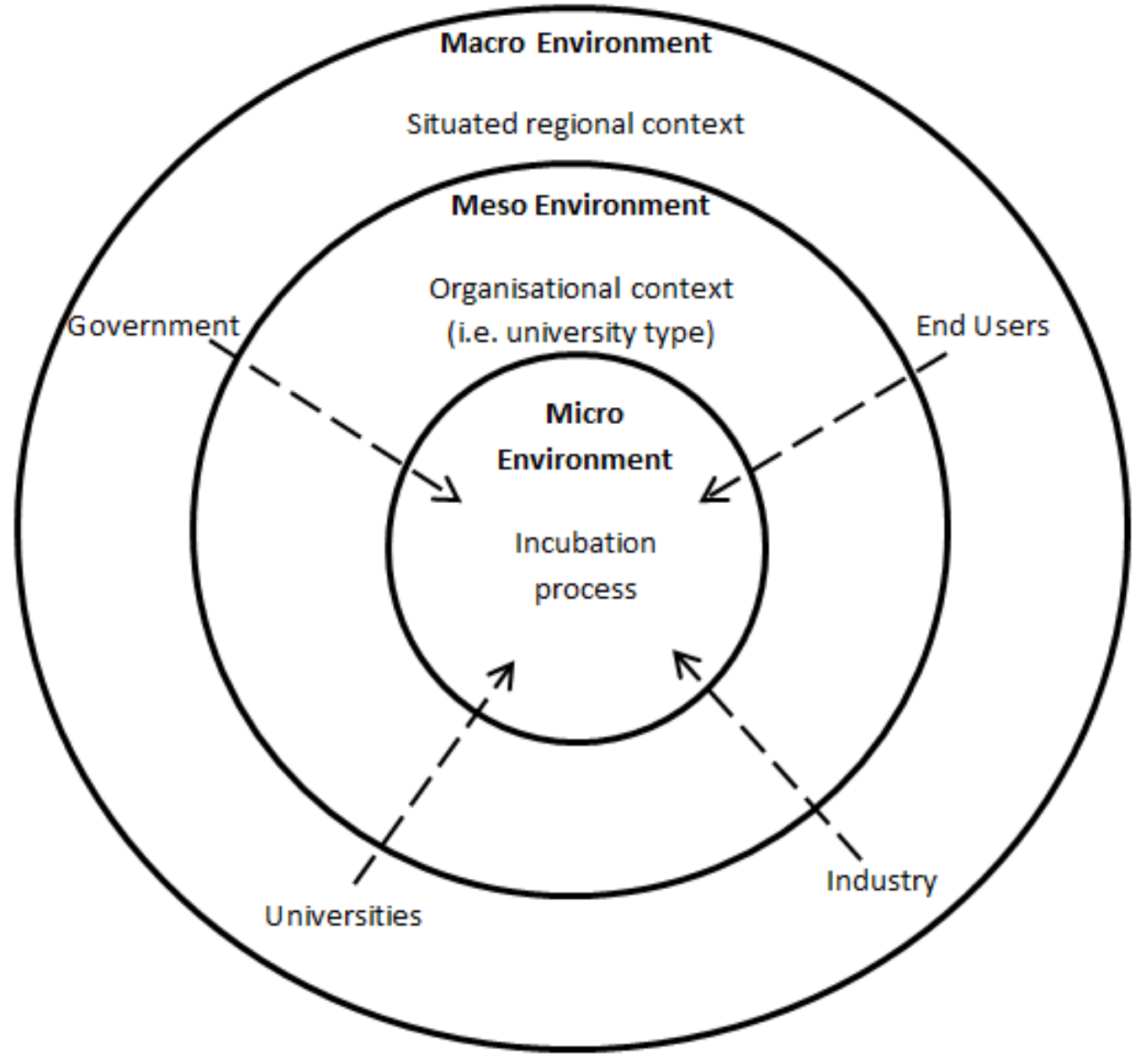

